\title{
Characterizing physiological status in three breeds of bulls reared under ecological and climate conditions of the Altai region
}

\author{
L.V. Osadchuk ${ }^{1,2 *}$, M.A. Kleschev ${ }^{1,2}$, O.I. Sebezhko ${ }^{1}$, O.S. Korotkevich ${ }^{1}$, N.I. Shishin ${ }^{1}$, \\ T.V. Konovalova ${ }^{1}$, K.N. Narozhnykh ${ }^{1}$ and V.L. Petukhov ${ }^{1}$
}

\begin{abstract}
${ }^{1}$ Federal State Budgetary Educational Institution of Higher Education "Novosibirsk State Agrarian University", ${ }^{2}$ Federal Research Center "Institute of Cytology and Genetics of the Siberian Branch of RAS", Novosibirsk, Russia.

"Corresponding Author: 10 Lavrentiev Ave., 630090, Phone: +7 92319322 46, e-mail: losadch@bionet.nsc.ru
\end{abstract}

(Received January 25, 2017; Accepted April 4, 2017)

\begin{abstract}
Ecological and climatic factors have an impact on the health, productivity and reproduction of the cattle. The goal of this work is the study of physiological status of servicing bulls reared under ecological and climate conditions of the Altai region, by defining the differences between Red-Steppe, Simmental and Black-and-White breeds in spermatogenic, hormonal, biochemical and hematological parameters. Samples of peripheral blood and ejaculates were taken from 48 grown-up servicing bulls (average age 5.6 \pm 0.3 years) in autumn period. It was established that Red-Steppe bulls have higher concentrations of nonorganic phosphorus, leucocytes, erythrocytes, hemoglobin, hematocrit and erythrocyte sedimentation rate in comparison with animals of Simmental breed, and the hemoglobin concentration and hematocrit are also higher in comparison with Blackand-White breed. It was noted that bulls of Black-and-White breed have a higher level of cortisol in comparison with the other breeds. The lowest level of serum urea and total protein and increased serum activity of creatine kinase and $\gamma$-glutamyl transferase, as well as the heaviest body weight were observed in Simmental breed bulls. The differences between breeds in a wide spectrum of physiological measures reflect not only genetically determined peculiarities of homeostatic mechanism, but also may reflect different ability to adapt to local ecological and climate conditions of the Altai region. Spermatogenic, biochemical and hematological measures in bull sires reared in the Altai region were similar to those in bulls bred in other Russian regions and some other countries. The measures reported could serve as reference values and therefore represent 'normal' values of physiological status for these bull sires reared in this ecological and climatic zone, but could be utilized in further studies for comprehensive monitoring of cattle breeding stock in other ecological and climatic zones of the Siberian region of Russia.
\end{abstract}

Keywords: Cattle, Breeds, Spermatogenesis, Cortisol, Thyroid hormones, Hematology, Blood biochemistry Available online at http://www.vetmedmosul.org/ijvs

$$
\begin{aligned}
& \text { توصيف الحالة الفيزيولوجية لثلاثة سلالات من الثيران التي تربى تحت الظروف البيئية والمناخية } \\
& \text { لمنطقة ألتاي في روسيا لاتيران التي }
\end{aligned}
$$

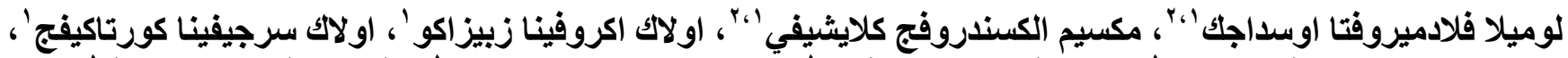

$$
\begin{aligned}
& \text { نيكولاي اوسوفج شيشان' ، تيتانه فلريفانا كونافولو '، كار ال نيكوليفج ناروزنكاي' و فلائلايره افريتفيج بيكلوفا' } \\
& \text { 'المركز القومي للبحوث، معهد الدراسات الجينية والخلوية لسبيريا فرع راس، 'آلكعهة العالي للارسات، نوفوسبرسك، الجامعة الزراعية، روسيا }
\end{aligned}
$$

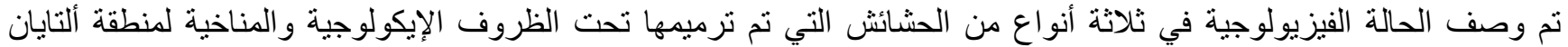

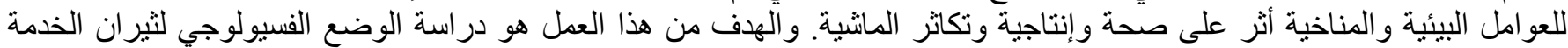




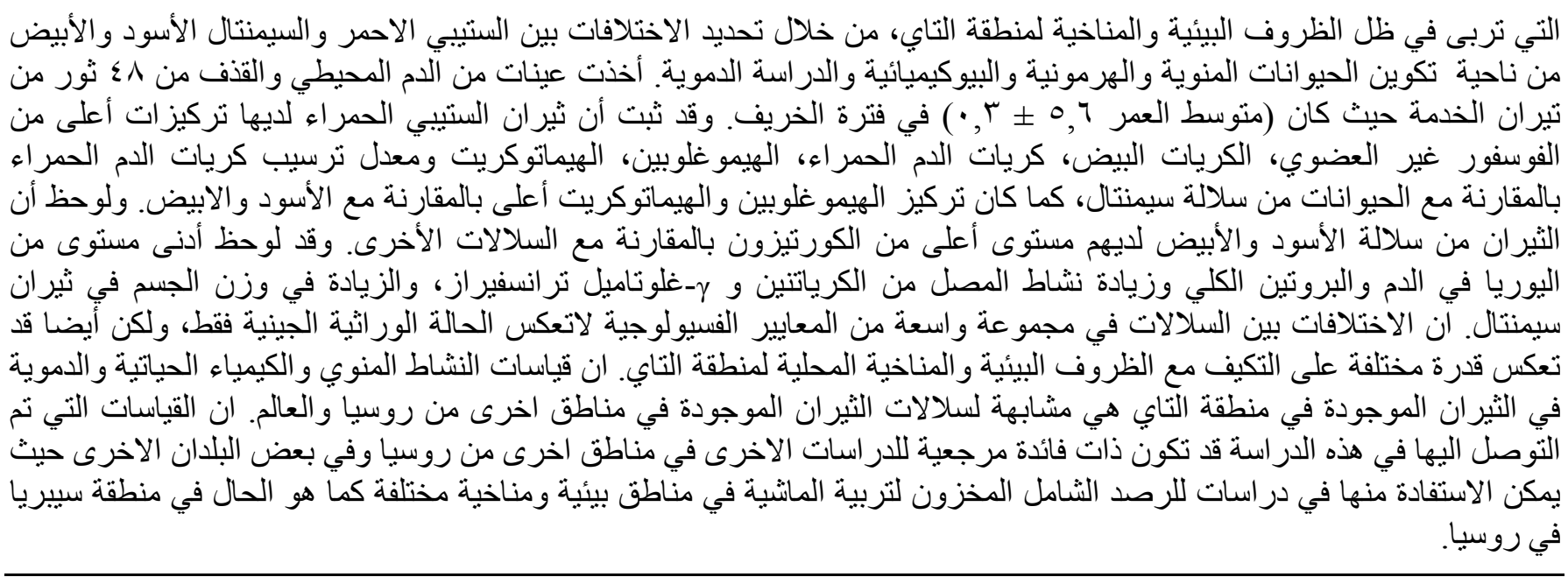

\section{Introduction}

Russia is characterized by a huge diversity of climatic conditions, soils and vegetation; therefore, breeds and types of farm animals ranched here are to have good adaptive features in order to realize their genetic potential. Our knowledge about the mechanisms of environmental and climatic effects on adaptation, productivity and reproduction of farm animals is not yet complete, in spite of considerable achievements in improvement of breeding conditions and diets (1). Recently, together with the traditionally increased attention to the issues of perfection of breeding-genetic work for the increase in productivity, strengthening of resistance to diseases and productive longevity of the cattle (2), the interest has grown to the search of cattle genotypes, which are the most resistant to the action of local unfavorable factors (3).

Environmental and climatic factors have an impact on the health, productivity and reproduction of the cattle; for this reason, the extension and deepening of our understanding of the climatic and anthropogenic effects on cattle health remains an actual problem. One of approaches to solve this problem is the comprehensive monitoring of animal physiological status in breeding farms situated at different locations; that will allow eliciting and evaluation of the temporary, environmental and climatic trends of adaptive and reproductive potential of cattle populations (4).

A wide distribution of artificial insemination in cattle breeding programs raises an issue about factors affecting sperm production in bull sires. This issue is especially important since artificial insemination is not only one of the most important tools to improve pregnancy rates, but also a tool for effective selection due to the use of the most valuable breeders (5). A number of factors including genetic background, age, varying quality of feed, environmental and specific climatic conditions affecting sperm quality (6-8). In bull sires, an evaluation of sperm fertilizing capability always includes determination of sperm concentration, motility and morphology, i.e. traits that constitute routine semen records in artificial insemination. Use of these sperm parameters allows monitoring the sire's reproductive potential in commercial artificial insemination centers for culling the animals with decreased reproductive efficiency. On the other hand, a stability of sperm quality gives a possibility to establish reference values for each cattle breed rearing in the specific ecological and climatic zone.

Additional indices of successful adaptation to environmental factors, which are involved in the mechanisms of homeostasis regulation, are levels of reproductive and adaptive hormones in the peripheral circulation. The hormonal status of animals determines the character of metabolism and is linked with all vital body functions including the reproductive function. All hormones are characterized by a high specificity of action and high biological activity including the impact on the gene expression (9). Among them, it is possible to highlight a few hormones that serve as markers of reproductive and adaptive potential. Testosterone is the main reproductive hormone in males that determines the development and support of male phenotype, regulates secondary sexual characters, growth of muscles, forming of sexual behavior, qualitative and quantitative indices of spermatogenesis, stimulates catabolic processes and erythropoiesis (10). Characteristic feature of glucocorticoids (the main glucocorticoid in the cattle is cortisol) is a broad spectrum of action including, primarily, catabolic effects, suppressive influence on the immune system and metabolism (9). Cortisol participates in realization and formation of adaptive reactions, and a higher cortisol level is the main indicator of stress. Thyroid hormones (thyroxine and triiodothyronine) are necessary for the normal growth and development; they modulate energy consumption, heat 
production, and body weight, stimulate erythropoiesis in bone marrow (9). The most well-known effect of these hormones is the increase of basal metabolism, which means the growth of oxygen consumption and the increase in heat production. The endocrine system is determined by genotype and environmental factors, in particular, climatic conditions of the region, nutritional management, the environment around the animals, infections and invasions (11). Therefore, the hormone concentration in peripheral blood of the cattle will reflect both hereditary traits and conditions of existence determining resistance and adaptation to the environment.

As known, the support of homeostasis is conducted through physiological mechanisms, among which biochemical and hematological parameters play the leading role. Hematological analysis is used for diagnostics of malfunction in haemopoiesis, organ and systemic diseases, as well as in combination with clinical tests - for assessment of clinical outcome and efficacy of a treatment in every specific case (12). Hematological parameters of farm animals provide useful information on non-specific resistance and adaptive capabilities in specific ecological and climatic conditions of breeding environment (12). Concentrations of metabolites and enzymes represent good indicators of trophic and immune status and they are widely used in veterinary medicine (13). In farm animals, monitoring of biochemical indices allows detecting metabolic disorders in time, evaluating the impact of ecological-climatic factors and stress on the body, correcting diets and livestock management technology. In addition, a serum enzyme level is a highly inherited character, which can be effectively used as a predictor of animals' productivity (2).

The issue of reference intervals for hormonal, hematological and biochemical indices in cattle at different locations remains extremely important and open due to breed-, sex-, and age-related features, as well as with the account of different ecological and climatic breeding zones (12-14). Practical application of given markers is very often limited by the absence of reference values in a specific region. At present, there are no adequate reference intervals for many indices of physiological status in some regions of Russia, what is partly due to the absence of the reference population of healthy animals required for their establishment. Besides that, changes of reference intervals may occur over time; they are connected with a genetic improving of population gene pool, use of new breeding technologies and a progressive improvement of animals' breeding conditions and parasitic monitoring.

The goal of the present study was to investigate the physiological status and to find out the differences between three breeds of bull sires bred in the ecological and climatic conditions of the Altai region by evaluating the spermatogenic, hormonal, biochemical and hematological parameters.

\section{Material and methods}

\section{Animals and location}

The study was performed in September-October 2015 at the commercial enterprise "Barnaulskoe" located in the town of Barnaul of the Altai region. The enterprise is engaged in stockbreeding and artificial insemination of cattle and supplies with semen to more than 800 cattle farms of the Altai region. The town is located in the south of Western Siberia in the forest-steppe zone on the bank of the $\mathrm{Ob}$ river on the same latitude that are Hamburg, Dublin, Liverpool, Minsk. The climate is continental, the winter is frosty, moderately severe and snowy, but the summer is warm, comfortable and moderately humid. The research included 48 healthy bull sires at the age of 2 to 10 years. The animals belonged to Red-Steppe breed (milk type, aged $4.4 \pm 0.5$ years, $n=13$ ), Simmental breed (milk type, aged $7.9 \pm 0.5$ years, $\mathrm{n}=12$ ) and Black-and-White breed (milk type, aged 5.0 \pm 0.5 years, $n=23$ ) and were kept in covered ventilated stables with daily motion. Roughage and mixed fodder produced at the breeding enterprise "Barnaulskoe" were used for feeding of animals; the level of heavy metals in these fodders did not exceed the permissible concentrations (15).

\section{Measurements and analyses}

Blood samples were obtained from jugular vein in the morning hours before feeding in the stables where the animals were kept. For hormonal analysis, the blood was collected into vacuum test glasses without any additions and centrifuged at $2000 \times \mathrm{g}$ for $20 \mathrm{~min}$; the serum was stored at $-40^{\circ} \mathrm{C}$ before the analysis. For analysis of hematological indices, vacuum test glasses with anticoagulant (K2 EDTA) were used, for biochemical analysis - with clot forming activator $\left(\mathrm{SiO}_{2}\right)$.

Ejaculates collected in compliance with the accepted protocol, according to which semen collection from every servicing bull was performed every 7 days with two or three collections per day with a short time interval, which were later pooled. Semen was collected with the use of an artificial vagina into a sterile plastic semen collector and weighed. The semen volume was assessed on the basis of the assumption that $1 \mathrm{ml}$ of ejaculate weighs $1 \mathrm{~g}$. Semen aliquot was dissolved in 3\% solution of sodium citrate, the proportion of motile spermatozoa was determined on the analyzer of sperm fertility AFS 500-2 ("Biola", Russia).

Sperm concentration was determined in Goryaev chamber under a light microscope (magnification $\times 200$ ) after staining of the ejaculate aliquot by trypan blue during a night. For assessment of sperm morphology, the native ejaculate aliquot was dissolved in phosphate buffer and a 
routine sperm smear was made and allowed to air dry. The air-dried slides were placed into $96 \%$ methanol for fixation and then stained using Gimza dye ("Biovitrum", Russia). The smears were covered with a cover slip using Canadian balsam. Morphology of the first 200 sperm cells was evaluated with a Carl Zeiss microscope (magnification $\times 1000$ ) with oil immersion. A sperm whose head, neck and tail corresponded to the accepted criteria (16) was considered morphologically normal.

Serum concentrations of testosterone, cortisol, thyroxine and triiodothyronine were determined in duplicate using commercial IFA kits ("Alkor Bio", Russia) according to the instructions of the manufacturer and with the use of spectrophotometer Multiscan («Thermo», Finland). Serum concentrations of total protein, glucose, total cholesterol, triglycerides, urea, calcium and non-organic phosphorus were determined by the enzyme colorimetric method with the use of commercial kits ("Vector Best", Russia). Activities of $\alpha$-amylase, lactate dehydrogenase, creatine kinase and $\gamma$-glutamyl transferase were evaluated with the enzyme colorimetric method (multi-point kinetics) by commercial kits ("Olveks Diagnostikum", Russia) according to the instructions of the manufacturer. Biochemical analyses were conducted using the semiautomatic biochemical analyzer Photometer 5010 ("Robert Riele GmbH", Germany).

Anti-coagulated blood was analyzed shortly after collection for measurements of leucocytes, erythrocytes, thrombocytes, hemoglobin, and hematocrit and erythrocyte sedimentation rate using automatic hematological analyzer PCE 90 Vet ("HTI", USA).

\section{Statistical Analysis}

The data are presented as mean \pm standard error. Before statistical analysis, all data were tested for normality by Kolmogorov-Smirnov criterion. If parameters were not normally distributed, they were transformed using the logarithmic transformation ( $\alpha$-amylase, creatine kinase and $\gamma$-glutamyl transpeptidase). The data were analyzed by the descriptive method and 1-way ANOVA using the package «STATISTICA 8.0». All parameters were compared between breeds by Duncan's test. A Pearson's correlation test was used to establish simple correlations between different parameters. Differences were considered statistically significant when $\mathrm{p}<0.05$.

\section{Results}

Body weight and semen quality parameters in three breeds of bulls are represented in Table 1. The 1-way ANOVA allowed detecting the effect of breed on the body weight $\left(\mathrm{F}_{2,45}=3.26, \mathrm{p}<0.05\right)$. The sires of Simmental breed were heavier that animals of other two breeds. Significant differences between breeds in ejaculate volume, concentration and proportion of motile and morphologically normal sperm were not detected.

Data on the hormonal status of animals are presented in Table 2. The influence of breed on the cortisol level (F2, $42=3.99, \mathrm{p}<0.05$ ) with higher values in Black-and-White breed in comparison with the two other breeds $(\mathrm{p}<0.05)$ was demonstrated. The testosterone, triiodothyronine and thyroxine levels did not statistically differ between the breeds.

Table 1: Body weight and semen quality parameters in bulls of three breeds reared in the Altai region

\begin{tabular}{lccccc}
\hline Breed & $\begin{array}{c}\text { Body weight, } \\
\mathrm{kg}\end{array}$ & $\begin{array}{c}\text { Ejaculate } \\
\text { volume, } \mathrm{ml}\end{array}$ & $\begin{array}{c}\text { Sperm concentration, } \\
\mathrm{mln} / \mathrm{ml}\end{array}$ & $\begin{array}{c}\text { Sperm motility, } \\
\%\end{array}$ & $\begin{array}{c}\text { Morphologically } \\
\text { normal sperm, \% }\end{array}$ \\
\hline Red-Steppe & $913 \pm 35^{\mathrm{b}}$ & $4.3 \pm 0.5$ & $1182 \pm 93$ & $76.2 \pm 2.5$ & $86.63 \pm 1.23$ \\
Simmental & $1019 \pm 21^{\mathrm{a}}$ & $4.4 \pm 0.4$ & $1002 \pm 77$ & $77.9 \pm 2.1$ & $85.84 \pm 1.89$ \\
Black-and-White & $930 \pm 26^{\mathrm{b}}$ & $4.7 \pm 0.4$ & $1018 \pm 73$ & $81.0 \pm 1.5$ & $88.83 \pm 1.07$ \\
\hline Mean & $948 \pm 17$ & $4.5 \pm 0.3$ & $1082 \pm 48$ & $79.0 \pm 1.1$ & $87.58 \pm 0.77$ \\
\hline
\end{tabular}

Here and further: all values are expressed as mean \pm SEM; ${ }^{a, b}$ values within column and variable differ $(\mathrm{p}<0.05)$.

Table 2: Serum hormone concentrations in bulls of three breeds reared in the Altai region

\begin{tabular}{lcccc}
\hline Breed & $\begin{array}{c}\text { Testosterone, } \\
\mathrm{nmol} / 1\end{array}$ & $\begin{array}{c}\text { Cortisol, } \\
\mathrm{nmol} / \mathrm{l}\end{array}$ & $\begin{array}{c}\text { Triiodothyronine }\left(\mathrm{T}_{3}\right), \\
\text { nmol/l }\end{array}$ & $\begin{array}{c}\text { Thyroxine }\left(\mathrm{T}_{4}\right), \\
\text { nmol/l }\end{array}$ \\
\hline Red-Steppe & $44.90 \pm 5.46$ & $32.75 \pm 5.08^{\mathrm{b}}$ & $2.15 \pm 0.13$ & $69.15 \pm 3.74$ \\
Simmental & $40.68 \pm 8.36$ & $31.53 \pm 1.54^{\mathrm{b}}$ & $2.36 \pm 0.17$ & $65.08 \pm 3.43$ \\
Black-and-White & $47.05 \pm 4.21$ & $45.35 \pm 3.87^{\mathrm{a}}$ & $2.09 \pm 0.10$ & $72.70 \pm 2.51$ \\
\hline Mean & $45.82 \pm 3.13$ & $38.34 \pm 2.48$ & $2.17 \pm 0.07$ & $69.83 \pm 1.81$ \\
\hline
\end{tabular}

The serum levels of main metabolites and enzymes in the bulls of three breeds are presented in Tables 3 and 4 .
The influence of breed on the urea level $\left(\mathrm{F}_{2,42}=4.44\right.$, $\mathrm{p}<0.05$ ) was found. The lower level of urea was noted in 
bulls of Simmental breed in comparison with the two other breeds $(\mathrm{p}<0.05)$. The level of nonorganic phosphorus in animals of Red-Steppe breed was higher in comparison with that of Simmental breed $(p<0.05)$. Significant differences in the levels of total cholesterol, triglycerides, glucose and calcium were not determined among breeds.

The influence of breed on $\gamma$-glutamyl transferase $\left(\mathrm{F}_{2,42}=3.39, \quad \mathrm{p}<0.05\right)$ and creatine kinase $\left(\mathrm{F}_{2,43}=3.77\right.$, $\mathrm{p}<0.05)$ was demonstrated. Simmental breed is characterized by the highest concentration of $\gamma$-glutamyl transferase compared to two other breeds and a higher concentration of creatine kinase compared to Red-Steppe breed. Simmental breed differed from Red-Steppe breed by lower total protein values $(\mathrm{p}<0.05)$. No differences were detected in the level of $\alpha$-amylase and lactate dehydrogenase between the breeds.

The influence of breed on the total number of leucocytes $\left(\mathrm{F}_{2,43}=4.83, \quad \mathrm{p}<0.05\right) \quad$ and erythrocytes $\left(\mathrm{F}_{2,44}=3.51, \mathrm{p}<0.05\right)$, hemoglobin level $\left(\mathrm{F}_{2,43}=5.47, \mathrm{p}<0.05\right)$, hematocrit $\quad\left(\mathrm{F}_{2,44}=6.26, \quad \mathrm{p}<0.05\right)$ and erythrocyte sedimentation rate $\left(F_{2,44}=3.54, p<0.05\right)$ is shown in Table 5 . The number of leucocytes, erythrocytes, and erythrocyte sedimentation rate was significantly higher in animals of Red-Steppe breed compared to those of Simmental breed $(p<0.05)$. The level of hemoglobin and hematocrit were significantly higher in Red-Steppe breed than in two other breeds $(\mathrm{p}<0.05)$.

Table 3: Serum metabolite concentrations in bulls of three breeds reared in the Altai region

\begin{tabular}{lcccccc}
\hline Breed & $\begin{array}{c}\text { Total cholesterol, } \\
\mathrm{mmol} / 1\end{array}$ & $\begin{array}{c}\text { Triglycerides, } \\
\mathrm{mmol} / 1\end{array}$ & $\begin{array}{c}\text { Urea, } \\
\mathrm{mmol} / 1\end{array}$ & $\begin{array}{c}\text { Glucose, } \\
\mathrm{mmol} / 1\end{array}$ & $\begin{array}{c}\text { Calcium, } \\
\mathrm{mmol} / 1\end{array}$ & $\begin{array}{c}\text { Phosphorus, } \\
\mathrm{mmol} / 1\end{array}$ \\
\hline Red-Steppe & $6.03 \pm 0.56$ & $0.51 \pm 0.08$ & $8.3 \pm 0.7^{\mathrm{b}}$ & $8.4 \pm 1.2$ & $4.5 \pm 0.8$ & $3.56 \pm 0.51^{\mathrm{a}}$ \\
Simmental & $5.01 \pm 0.56$ & $0.37 \pm 0.05$ & $5.4 \pm 1.1^{\mathrm{a}}$ & $8.1 \pm 0.7$ & $4.0 \pm 0.5$ & $2.32 \pm 0.46^{\mathrm{b}}$ \\
Black-and- & $4.93 \pm 0.51$ & $0.48 \pm 0.05$ & $8.0 \pm 0.5^{\mathrm{b}}$ & $8.3 \pm 0.8$ & $3.4 \pm 0.4$ & $2.47 \pm 0.31^{\mathrm{ab}}$ \\
White & $5.23 \pm 0.32$ & $0.46 \pm 0.03$ & $7.5 \pm 0.4$ & $8.3 \pm 0.5$ & $3.8 \pm 0.3$ & $2.72 \pm 0.24$ \\
\hline Mean & & &
\end{tabular}

Table 4: Serum total protein and enzyme concentrations in bulls of three breeds reared in the Altai region

\begin{tabular}{lccccc}
\hline \multirow{2}{*}{ Breed } & $\begin{array}{c}\text { Total protein, } \\
\mathrm{g} / 1\end{array}$ & $\begin{array}{c}\text { Creatine kinase, } \\
\mathrm{U} / 1\end{array}$ & $\begin{array}{c}\gamma \text {-glutamyl } \\
\text { transferase, } \mathrm{U} / 1\end{array}$ & $\begin{array}{c}\alpha \text {-amylase, } \\
\mathrm{U} / 1\end{array}$ & $\begin{array}{c}\text { Lactate dehydrogenase, } \\
\mathrm{U} / 1\end{array}$ \\
\hline Red-Steppe & $90.4 \pm 2.9^{\mathrm{b}}$ & $99.0 \pm 12.9^{\mathrm{b}}$ & $16.9 \pm 1.0^{\mathrm{b}}$ & $34.0 \pm 3.4$ & $421.9 \pm 16.7$ \\
Simmental & $78.1 \pm 4.1^{\mathrm{a}}$ & $173.1 \pm 25.8^{\mathrm{a}}$ & $23.5 \pm 3.4^{\mathrm{a}}$ & $36.7 \pm 5.6$ & $378.2 \pm 29.8$ \\
Black-and-White & $87.0 \pm 3.6^{\mathrm{ab}}$ & $130.0 \pm 13.2^{\mathrm{ab}}$ & $17.2 \pm 1.2^{\mathrm{b}}$ & $35.2 \pm 4.6$ & $367.8 \pm 22.8$ \\
\hline Mean & $85.6 \pm 2.2$ & $133.2 \pm 10.4$ & $18.7 \pm 1.1$ & $35.3 \pm 2.8$ & $399.1 \pm 10.3$ \\
\hline
\end{tabular}

Table 5: Blood hematological parameters in bulls of three breeds reared in the Altai region

\begin{tabular}{lcccccc}
\hline Breed & $\begin{array}{c}\text { Leucocytes, } \\
10^{9} / \mathrm{L}\end{array}$ & $\begin{array}{c}\text { Erythrocytes, } \\
10^{12} / \mathrm{L}\end{array}$ & $\begin{array}{c}\text { Platelets, } \\
10^{9} / \mathrm{L}\end{array}$ & $\begin{array}{c}\text { Hemoglobin, } \\
\mathrm{g} / \mathrm{L}\end{array}$ & $\begin{array}{c}\text { Hematocrit, } \\
\%\end{array}$ & $\begin{array}{c}\text { Erythrocyte sedimentation } \\
\text { rate, mm/hour }\end{array}$ \\
\hline Red-Steppe & $6.71 \pm 0.38^{\mathrm{a}}$ & $7.9 \pm 0.2^{\mathrm{a}}$ & $198 \pm 24$ & $140 \pm 6^{\mathrm{a}}$ & $38.6 \pm 1.6^{\mathrm{a}}$ & $0.55 \pm 0.08^{\mathrm{a}}$ \\
Simmental & $4.59 \pm 0.47^{\mathrm{b}}$ & $7.2 \pm 0.2^{\mathrm{b}}$ & $192 \pm 29$ & $122 \pm 3^{\mathrm{b}}$ & $32.6 \pm 1.2^{\mathrm{b}}$ & $0.29 \pm 0.06^{\mathrm{b}}$ \\
Black-and- & $5.75 \pm 0.38^{\mathrm{ab}}$ & $7.4 \pm 0.1^{\mathrm{ab}}$ & $205 \pm 18$ & $127 \pm 2^{\mathrm{b}}$ & $35.0 \pm 0.7^{\mathrm{b}}$ & $0.44 \pm 0.05^{\mathrm{ab}}$ \\
White & & & & & \\
\hline Mean & $5.73 \pm 0.26$ & $7.5 \pm 0.1$ & $200 \pm 13$ & $130 \pm 2$ & $35.3 \pm 0.7$ & $0.43 \pm 0.04$ \\
\hline
\end{tabular}

\section{Discussion}

Importance of cattle breeding population's monitoring in different ecological and climate conditions of Russia including the Altai region is determined, in the first place, by the necessity to maintain a high reproductive capacity of animals, preserve and improve the population gene pool (4). In this respect, principally important is the capability to characterize the general health of animals using diagnostic and prognostic potential of spermatogenic, hormonal, biochemical and hematologic markers, and, with reference to breeding herd, give an objective evaluation of the fertility potential. Ideal is the development of reference limits of physiological markers in every ecological and climatic region, but this is connected with considerable difficulties due to the insufficient number of animals, a wide variability of diets and technologies of cattle management in the same region, which affects the 
physiological parameters, especially of metabolic and hormonal profile.

At laboratory evaluation of commercially produced bull semen, it is important to detect animals with low measures, as in view of countrywide distribution of the artificial insemination, it is necessary to be sure in animals' capability to produce a sufficient amount of sperm with high fertilizing capacity. Removal of the sires with poor semen quality but with high virtues leads to considerable economical losses both in breeding farms and livestock production sector as a whole. As a rule, in commercial artificial insemination centres, the fertility potential of bull sires is evaluated by mating performance, scrotal circumference and spermatogenic parameters including sperm concentration, motility and morphology, which closely correlate with bull's fertility (17).

Comparison of sperm motility, morphology and concentration in servicing bulls in "Barnaulskoe" breeding farm and other farms in Russia and some other countries gave the following results. In bulls of Black-and-White breed from "Bryanskoe" breeding farm of the Bryansk region, sperm concentration was in average $1.00 \mathrm{bln} / \mathrm{ml}$ and percentage of morphologically normal sperm was not lower than $86 \%$ (18); that agrees with the data of our research. Comparison of Simmental breed bulls from "Barnaulskoe" breeding farm and a breeding center in Austria (8) showed that ejaculate volume in Altai animals was smaller than that in Austrian animals ( $4.4 \pm 0.4$ and $5.8 \pm 2.6 \mathrm{ml}$, respectively), but sperm concentration was not different $(1.0 \pm 0.08$ and $1.3 \pm 0.4 \mathrm{bln} / \mathrm{ml}$, respectively). In 502 Holstein bulls bred in Spain, the average ejaculate volume of $5.49 \mathrm{ml}$ and sperm concentration of $1.27 \mathrm{bln} / \mathrm{ml}$ (6) were somewhat higher than the average values of same parameters in Altai bulls, however, among which there were no animals of Holstein breed.

Some authors reported notable differences in semen production and quality between individual bulls connected with effects of age, season and breed (19). In Fleckvieh breed bulls, the ejaculate volume varied within the range of 5.98-11.59 $\mathrm{ml}$ and the sperm concentration within the range of 0.32-2.26 bln/ml (19). In Bos indicus and Bos Taurus bulls bred in Brazil, the seasonal differences were observed in sperm concentration, which varied within 1.4-1.6 and 1.2-1.3 bln/ml, respectively (20). In our study, ejaculate volume varied within the limits of $2.3-10.0 \mathrm{ml}$ and the sperm concentration within the limits of $0.40-1.86 \mathrm{bln} / \mathrm{ml}$. Thus, notwithstanding the considerable variability of seminal characteristics, the average values of ejaculate volume and sperm concentration are perfectly well comparable to the values in different regions of Russia and some other countries, which are different in climate and ecological situation; that proves relative stability of bulls' sperm production independent of the breed and breeding region.
It is known that the conception rate and further successful embryonic survival is largely dependent on sperm morphological structure $(21,22)$. It is acknowledged that in a healthy and sound bull, more than $70 \%$ percent of sperm must have normal morphology. In our group of animals, the proportion of morphologically normal sperm varied between 73 and 96\%. However, taking into consideration the fact that various factors contribute to bull fertility, no single diagnostic test can accurately predict fertility, including sperm morphology test. In the studied group of animals, there were no correlations between main semen traits: sperm concentration, the proportion of morphologically normal and progressively motility sperm. These facts are confirmed by other authors; for example, reliable coefficients of correlation were not found between concentration and morphological qualities of sperm in a few cattle breeds (Holstein-Frisian, Simmentale, Limousine, Piemontese, Charolaise), but at low concentrations of sperm the relation between them became statistically significant (22).

In our study, the breed differences were not found in sperm concentration, motility and morphology, which agrees with the data of other researchers. No differences were found in daily sperm production, motility and morphology in cross-bred bulls when crossing breeds of Angus, Simmental and Hereford (23), as well as in pure and cross-bred bulls of Jersey breed (24). However, the higher sperm motility has been demonstrated in Holstein breed bulls compared to Belgian Blue breed, indicating the genetic component in sperm motility control (25). It is reasonable to assume that improving the environment around the animals and nutritional management, long-time and effective genetic selection for reproductive efficiency, as well as crosses with other breeds, dramatically increased sperm concentration and motility that in part could ultimately reduce the breed differences related to semen parameters.

In our study, the serum testosterone level in bulls considerably varied from 6.52 up to $88.74 \mathrm{nmol} / \mathrm{l}$, which was not connected with breed or age. In the bulls of Angus beef breed, the testosterone level considerably increases during puberty and reaches $15.0-21.0 \mathrm{nmol} / \mathrm{l}$ by the age of 1.5 years, changing little by the age of 3 years $(26,27)$; this level was significantly lower than the testosterone level in bulls in our study. In adult bulls of dairy breed reared in the State of Wisconsin (USA), the testosterone concentration ranged from $8.1 \mathrm{up}$ to $17.1 \mathrm{ng} / \mathrm{ml}$ (28), that corresponded to our data $(13.2 \pm 0.9 \mathrm{ng} / \mathrm{ml})$. In Holstein breed bulls bred in Japan, the testosterone level varied from 7.7 up to 13.3 $\mathrm{ng} / \mathrm{ml}$ and was comparable to the data of our work (29). Thus, it is possible to assume that the type of breed productivity significantly contributes to testicular testosterone production. It is interesting to note that the levels of triiodothyronine and thyroxine in bulls from the 
Altai enterprise and in Indian lactating buffalos kept in comfortable temperature and humidity conditions (30) are practically the same, taking into consideration the absence of sex differences in the basal level of these hormones (9).

Today, at the existing system of cattle breeding, a little attention is paid to monitoring of the blood enzyme activity, though some enzymes can be used as potential biomarkers of immunometabolic status, metabolic disorders or impact of non-balanced diet on animal health and productivity $(1,2)$. The serum concentration of total protein is considered as a generally accepted marker of protein metabolism. In our study, the average concentration of total protein in bulls $(85.6 \pm 2.2 \mathrm{~g} / \mathrm{l})$ is in agreement with previous observations obtained for a stock of 9-months-old bulls of beef-dairy "Bestuzhevskaya" breed $(82.8 \pm 2.3 \mathrm{~g} / \mathrm{l})$ and cross-breed bulls ("Bestuzhevskaya" x "Limousine", $84.5 \pm 1.3 \mathrm{~g} / \mathrm{l}$ ) in the Saratov region of Russia (31). Among three breeds used in our study, the lowest level of total protein was observed in Simmental breed of beef-dairy type of productivity, which was associated with a decreased level of protein metabolism in this breed. Additionally, among three breeds, the highest activity of creatine kinase and $\gamma$-glutamyl transferase was also determined in Simmental breed, which was associated with the increased body weight. Perhaps, a higher activity of creatine kinase in Simmental breed bulls reflects an increased demand for energy consumption of muscular tissue and a higher activity of $\gamma$-glutamyl transferase reflects a higher enzyme activity of liver cells. In general, a lower level of urea and total protein, a higher activity of creatine kinase and $\gamma$-glutamyl transferase and a large body weight characterize the peculiarities of protein metabolism in Simmental breed beef-dairy bulls. The obtained data confirm that the type of breed productivity plays an important part in determination of enzyme activity in bull sires.

In biochemical analysis, special attention has been paid to calcium and non-organic phosphorus because they serve as main indicators of mineral metabolism and have regulatory, metabolic and structural functions. In the present research, the serum calcium and phosphorus concentrations coincided with those of 9-months-old bull sires of beef-dairy "Bestuzhevskaya" breed and crossbreed bulls ("Bestuzhevskaya" $x$ "Limousine") reared in the Saratov region of Russia (31). In addition, the serum nonorganic phosphorous concentration in Red-Steppe breed bulls was higher than in Simmental breed bulls and was associated with a higher content of total serum protein.

In our research, all hematological parameters in bulls varied within reference intervals accepted for the cattle bred in Canada, Germany and USA $(12,14)$. In adult bulls bred in the South Urals, the total number of erythrocytes was 5$10 \times 10^{12} / 1$, hemoglobin concentration ranged $80-150 \mathrm{~g} / \mathrm{l}$ and hematocrit was $24-46 \%(32,33)$, that also corresponds to the data of our study. In Red-Steppe breed bulls, the hemoglobin concentration and hematocrit were higher than in both Simmental and Black-and-White breed, and the total number of leucocytes, erythrocytes, and erythrocyte sedimentation rate were higher than in Simmental breed. Evidently, these hematological features of Red-Steppe breed reflect a higher intensity of metabolic processes and a higher body demand for oxygen. Along with a higher content of non-organic phosphorous, they characterize a good adaptiveness of this breed to harsh continental climate of the Altai region.

\section{Conclusion}

The spermatogenic, hormonal, biochemical and hematological parameters, which characterize the physiological status of bull breeding stock in the Altai region can be used as reference values for this region, as well as, probably, at monitoring of cattle populations in other Siberian regions. However, because of the small sample size, future studies will be needed to verify the usefulness of these biomarkers as predictors of animal health in this region; that will help improve animal health and productivity. Physiological parameters characterizing reproductive and adaptive health of bull sires bred in the Altai region are in line with bull indices from other Russian regions and some other countries. This fact allowed us to conclude that genetic background and keeping technology of the animals under the given environmental and climate conditions are optimal for these breeds.

\section{Acknowledgements}

This research was supported by the Russian Science Foundation (project № 15-16-30003).

\section{References}

1. Collier RJ, Dahl GE, VanBaale MJ. Major advances associated with environmental effects on dairy cattle. J Dairy Sci. 2006;89:1244-1253.

2. Kudrin AG. Forecast of milk productivity of cattle according to activity of blood enzymes (review). Agricul Biol. 2003;2:8-11.

3. McNamara JP. A systems approach to integrating genetics, nutrition, and metabolic efficiency in dairy cattle. J Anim Sci. 2012;90:18461854.

4. Zheltikov AI, Petukhov VL, Korotkevich OS, Kostomakhin NM, Soloshenko VA, Klimenok II, Ufimtseva NS, Adushinov DS, Golubkov AI, Kuznetsov AI. Black-and-White Cattle of Siberia. Novosibirsk, NGAU. 2010:p.500.

5. Petukhov VL, Korotkevich OS, Stambekov SZh, Zhigachev AI, Bakai AV. Genetics. Novosibirsk, NSAY. 2007:p.628.

6. Karoui S, Diaz C, Serrano M, Cue R, Celorrio I, Carabano MJ. Time trends, environmental factors and genetic basis of semen traits collected in Holstein bulls under commercial conditions. Anim Reprod Sci. 2011;124:28-38.

7. Silva MR, Pedrosa VB, Borges-Silva JC, Eler JP, Guimarres JD, Albuquerque LG. Genetic parameters for scrotal circumference, breeding soundness examination and sperm defects in young Nellore bulls. J Anim Sci. 2013;91:4611-4616. 
8. Fuerst-Walt B, Schwarzenbacher H, Perner C, Sölkner J. Effects of age and environmental factors on semen production and semen quality of Austrian Simmental bulls. Anim Reprod Sci. 2006;95:27-37.

9. Gardner D, Shoback D. Greenspan's Basic and Clinical Endocrinology. 9th ed. The McGraw-Hill Companies, Inc. 2011:p.880.

10. Kronenberg HM, Melmed S, Polonsky KS, Larsen PR. Williams Textbook of Endocrinology. 13th edition. Elsevier Ltd. 2015:p.1936.

11. Bova TL, Chiavaccini L, Cline GF, Hart CG, Matheny K, Muth AM, Voelz BE, Kesler D, Memili E. Environmental stressors influencing hormones and systems physiology in cattle. Reprod Biol Endocrinol. 2014;12:58.

12. Roland L, Drillich M, Iwersen M. Hematology as a diagnostic tool in bovine medicine. J Vet Diagn Invest. 2014;26:592-598.

13. Ingvartsen KL, Moyes K. Nutrition, immune function and health of dairy cattle. Animal. 2013;7Suppl1:112-122.

14. George JW, Snipes J, Lane VM. Comparison of bovine hematology reference intervals from 1957 to 2006. Vet Clin Pathol. 2010;39(2):138-148.

15. Barth AD, Oko RJ. Abnormal morphology of bovine spermatozoa. First edition. Wiley-Blackwell, 1991:p.285.

16. Petukhov VL, Syso AI, Narozhnykh KN, Konovalova TV, Korotkevich OS, Sebezhko OI, Kamaldinov EV, Osadchuk LV. Accumulation of $\mathrm{Cu}$ and $\mathrm{Zn}$ in the soils, rough fodder, organs and muscle tissues of cattle in Western Siberia. RJPBCS. 2016;7(4):24582464.

17. Parkinson TJ. Evaluation of fertility and infertility in natural service bulls. Vet J. 2004;168(3):215-229.

18. Vashchekin EP, Diachenko AP. Metabolism and semen production of sires using in the ration the ground bean of blue lupine. Agricul Biol. 2008;4:58-63.

19. Igna V, Moje A, Mircu C, Roman M, Ghiurca C, Casalean D, Cernescu H. The influence of some environmental factors and age on semen production of Fleckvieh bulls. Lucrări Ştiintifice Medicină Veterinară. 2010;XLIII(2):56-63.

20. Koivisto MB, Costa MTA, Perri SHV, Vicente WRR. The effect of season on semen characteristics and freezability in Bos indicus and Bos taurus bulls in the southeastern region of Brazil. Reprod Dom Anim. 2009;44:587-592.

21. Al-Makhzoomi A, Lundeheim N, Haard M, Rodríguez-Martínez H. Sperm morphology and fertility of progeny-tested AI dairy bulls in Sweden. Theriogenology. 2008;70(4):682-691.
22. Kondracki S, Banaszewska D, Wysokicska A, Iwanina M. The effect of sperm concentration in the ejaculate on morphological traits of bull spermatozoa. Folia biologica (Krakyw). 2012;60(1-2):85-91.

23. Coulter GH, Cook RB, Kastelic JP. Effects of dietary energy on scrotal surface temperature, seminal quality, and sperm production in young beef bulls. J Anim Sci. 1997; 75:1048-1052.

24. Kumar U, Gawande AP, Sahatpure SK, Patil MS, Lakde CK, Bonde SW, Borkar PL, Poharkar AJ, Ramteke BR. Assessment of semen quality in pure and crossbred Jersey bulls. Vet World. 2015;8(10):1266-1272.

25. Hoflack G, Opsomer G, Rijsselaere T, Van Soom A, Maes D, de Kruif A Duchateau L. Comparison of computer-assisted sperm motility analysis parameters in semen from Belgian Blue and HolsteinFriesian bulls. Reprod Dom Anim. 2007;42:153-161.

26. Brito LFC, Barth AD, Rawlings NC, Wilde RE, Crews DH, Mir PS, Kastelic JP. Circulating metabolic hormones during the peripubertal period and their association with testicular development in bulls. Reprod Dom Anim. 2007a;42:502-508.

27. Brito LFC, Barth AD, Rawlings NC, Wilde RE, Crews DH, Boisclair YR, Ehrhardt RA, Kastelic JP. Effect of feed restriction during calfhood on serum concentrations of metabolic hormones, gonadotropins, testosterone, and on sexual development in bulls. Reprod. 2007b;134:171-181.

28. Carter AL, Hutson SM, Stratman FW, Haning RV. Relationship of carnitine and acylcarnitines in ejaculated sperm to blood plasma testosterone of dairy bulls. Biol Reprod. 1980;23:820-825.

29. Devkota B, Takahashi K-I, Matsuzaki S, Matsui M, Miyamoto A, Yamagishi N, Osawa T, Hashizume T, Izaike Y, Miyake Y-I. (2011): Basal levels and GnRH-induced responses of peripheral testosterone and estrogen in Holstein bulls with poor semen quality. J Reprod Dev. 2011;57:373-378.

30. Chaudhary SS, Singh VK, Upadhyay RC, Puri G, Odedara AB, Patel PA. Evaluation of physiological and biochemical responses in different seasons in Surti buffaloes. Vet World. 2015;EISSN:22310916.

31. Yunusheva TN, Khakimov IN, Seitov MS. Genotype influence on morphological and biochemical indexes of animals' blood. Vestnik of the Orenburg State University, № 10, 2006; Part 2:p.371-373.

32. Litvinov KS, Kosilov VI. Hematological indices of Red Steppe saplings. Herald of beef cattle breeding. 2008;Part 61(1):148-154.

33. Kosilov VI, Mironenko SI, Zhukova OA. Hematological indexes of heifers with different genotypes in the South Urals. Herald of beef cattle breeding, 2009;Part 62 (1):150-158. 